UDC $549.1: 53: 622.765 .06$

\title{
精密交流ブリッジの試作とその応用*
}

$\begin{array}{llllll}\text { 正会員 } & \text { 下 } & \text { 飯 坂 潤 } & \text { 三*1 } \\ \text { 正会員 } & \text { 日 } & \text { 井 進 } & \text { 之 } & \text { 助 }^{* 2} \\ \text { 正会員 } & \text { 松 } & \text { 岡 } & & \text { 功 }^{* 3} \\ & & \text { 池 } & \text { 上 } & \text { 恒 } & \text { 男 }^{* 4} \\ \text { 正会員 } & \text { 早 } & \text { 川 } & \text { 典 } & \text { 久 }^{* 1}\end{array}$

\section{Application of A. C. Bridge for High Impedance Samples}

Junzo SHIMOIIZAKA, Shinnosuke USUI, Isao MATSUOKA, Tsuneo IKENOUE and Norihisa HAYAKAWA

An a. c. bridge for high impedance samples is constructed, and measurements of the electrical conductivity and the dielectric constant are made on the specimens of limestones at the frequency of 30 , $100,300,1000,3000$ c.p:s., respectively.

The electrical conductivity of the thermoluminescent limestone increases with the frequency more rapidly, in the range of $10^{-11} \sim 10^{-9} \Omega^{-1} \cdot \mathrm{cm}^{-1}$, than that of the nonthermoluminescent limestone, while the dielectric constant doesn't depend particularly on the frequency.

The conductometric titration is also made on the dilute solution of potassium ethyl xanthate using silver nitrate solution as a titrant. It is possible to quantify the potassium ethyl xanthate in the concentration of $5 \times 10^{-6} \mathrm{~mol} / l$.

\section{1. 緒言}

鉱物の電気伝導度, 誘電率, 誘電損失なぞの電気的性 質を研究することは鉱物の物性論的研究の一手段として 有用であるばかりでなく, 応用地学あるいは選鉱学の研 究分野においても重要な意義をもつている。このような 電気的性質を測定する一つの方法として交流ブリッジ法 を挙げることが出来るが，これまでの交流ブリッジでは 以下に述べ理由から平衡点の検出精度が不十分のため に, とくに試料のインピーダンスが高くなると, 電導度 分と容量分の分離が完全に行なわれないので十分な結果 を得ることが出来なかつた。すなわち，1）これまでの 交流ブリッジは多くの場合検出にトランスを用いており そのインピーダンスを余り高くすることが出来ないため に，高インピーダンス試料を測定しょうとする場合はブ リッジ辺の比を大きくとらなければならないが，このよ うにすると別の悪条件が生じて事実上高インピーダンス 試料の測定は困難となつてしまう。2) たとえこれらの

\footnotetext{
* 昭和36年12月14日受理

*1 工博 東北大学助教授 工学部鉱山学教室

*2 東北大学助教授 選釷製鍊研究所

*3 東北大学助手 工学部鉣山学教室

*4 東北大学助教授 非水溶液化学研究所
}

条件が解決されたとしてもトランス自体の周波数特性の ために測定範囲は非常に狭く制限されてしまう。3）下 ランスから雑音をひろう。これはいわゆる外部雑音だけ ではなく, 測定周波数自身の雑音もひろうので平衡点が 不明瞭になつたり誤差の原因になる。

以上述べたような事情から，交流ブリッジ汇よる高イ ンピーダンス試料の測定に関する実験はほとんど行なお れていなかつた。しかしながら, 研究の対象として高イ ンピーダンス試料を取扱わなければならない場合がしば しばあるので，この目的にかなうような交流ブリッジの 試作を行ない，試作装置の性能試験を兼㸚て一，二の測 定を行なつた結果，一応所期の目的を達したのでここに 報告する次第である。

\section{2. 試 作 の 概 要}

試作における基本的な要点は“真空管のグリッド回路 は高いインピーダンスを作ることが出来る”ということ に着目して，従来用いられているトランスを用いて不平 衡電圧を検出する代りに真空管平衡増幅回路を用いる点 にある。真空管回路を用いると，トランスを使用した場 合に問題になるマグネチックシールドが簡単に解決され るという利点の得られることも一つの特徴と考えられよ 


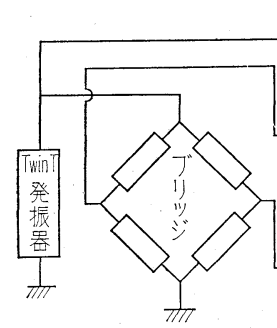

(B)

(A)

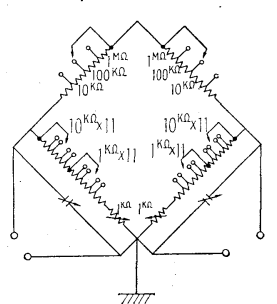

(A)

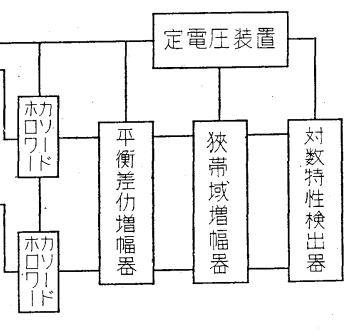

(E)

$(F)$

第1図·交流ブリッジのブロックダイアグラム

う。第 1 図に装置のブロックダイアグラムを示す*。(A) はブリッジ部であるが，この製作にあたつてはブリッジ 辺を出来るだけ, 左右対称作ること, 配線, スイッチ 類は十分絶縁の良いものを使用する等の点に注意しなけ ればならない。抵抗類は残留インピーダンスの影響を考 慮して, ホイートストンブリッジで校正されたカーボン 抵抗を用いた。Cは 12 430pF のラジオ用空気可変コ ンデンサーである。発振器 (B) は高調波を可及的に減 ずるために，周波数それぞれ $30 ， 100 ， 300 ， 1000 ， 3000$ サイクルに一定された Twin T 発振器を用いた。ブリ ッジ出力は (C) のカソードホロワーで受けられるので 入カインピーダンスは非常に高くとることが出来, 一方 出力インピーダンスは低くすることが出来る。カソード ホロワーの出力は (D) の平衡差動増幅器によつてブリ ッジ両端の出力の差だけが増幅され, 次段の狭帯域増幅 器 (E) に入る。ここでは再び Twin T の負饋還によ つて基本波に対してだけ鋭い増幅特性を持たせることに より高調波抢よび雑音を除き $\mathrm{SN}$ 比を上げ, 最後に対数 特性検出器 (F) で真空管の陽極電流の変化から平衡点 の検出を行なら。対数特性検出器の特徴として, 平衡点 付近では非常に高い感度有するが平衡点から離れると 感度が落ちるためにメーターの振り切れがない。

回路構成は以上の上うであるが, 問題はこのような真 空管回路を使用して何等の妨害もなしにその機能を発揮 させることが出来るかという技術的な点に存在する。こ のために安定度 $10^{-3}$ 程度の定電圧装置 $(\mathrm{G})$ が要求さ れ, また高感度増幅器 (検出感度は約 $0.6 \mu \mathrm{V}$ ) で問題 となる雑音を出来るだけ減ずるためと, 交流点火により

\footnotetext{
* 回路の詳細は池上により別に報告される予定である。
}

混入する交流電圧を除くために電源および発振器以外の 回路の真空管はすべて直流点火にした。

\section{3. 応用例}

\section{$3 \cdot 1$ 熱発光石灰岩の誘電率および電導度の周波数特 性について}

石灰岩の熱発光現象の物性論的ならびに鉱床学的研究 については筆者らの1人（早川）によつてすでに報告さ れているが和, その研究において熱発光石灰岩の誘電率, 電導度などの測定が要望されたのであるが, 石灰岩の電 導性が低いために, この目的を果し得ない状態にあつた ので，本試作装置を用いて石灰岩試料の誘電率あるいは 電導度を測定した場合どのような結果が得られるかにつ いて検討を行なつた。

（A）試料および測定方法：供試石灰岩は岩手県気仙 郡矢作町産の古生代石灰岩 4 種で, このうち 2 種は熱発 光性を有し他の 2 種はこれを有しない。試料は直径 $2 \mathrm{~cm}$ 厚さ $0.1 \mathrm{~cm}$ の円板に研摩整形し, ベンゾール次いでメ タノールで良く洗浄し一旦デシケーター中に保存する。 試料は測定に先立つて第 2 四に示すような装置によつて その両面に銀の真空蒸着を行なうが, 蒸着銀電極の縁端 効果のむらと表面電導をなくすために試料の一面は第 2 図( b ) 亿示すような有孔ガラス板を型として用い直径約 $0.6 \mathrm{c}$ のの形に, 裹面は全面に蒸着を行なつた。試料は シールドケース内に収め支持電極は同軸ケーブルでブリ ッジ辺に連結した。第 1 図でもわかるように試料は右辺 に插入して置換法によつて測定を行ならが，結線にもと ゔ容量および電導度の温度変化などを補償するため に，左辺にも右辺と対称河同軸ケーブルを結線する必要

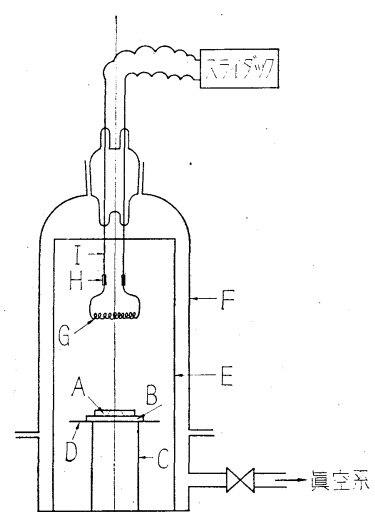

(a)

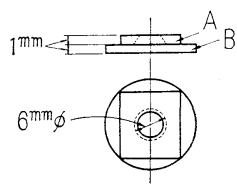

(b)
A : 有孔ガラス板

$\mathrm{B}$ : 誠料

$\mathrm{C}:$ 試料保持ガラス円 筒

$\mathrm{D}$ : 顕微鏡 用スライ $\mathrm{k}$ ガラス

$\mathrm{E}:$ ガラス阴筒

$\mathrm{F}: \mathrm{F}$ ガラス外筒

$\mathrm{G}$ :タングステンフィ ラメント

$\mathrm{H}:$ : ッケル線

I : 銅線

第 2 図 真空蒸着装置 
がある。

いまブリッジターミナルに試料を挿入しない状態でブ リッジを平衡させた時の右辺の抵抗と容量の值をそれぞ れ $R_{1}, C_{1}$, 試料老插入した時のそれらを $R_{2}, C_{2}$ とすれ ば，試料の抵抗および容量 $R_{x}, C_{x}$ はそれぞれ (1)，(2) 式によつて求められ, 試料の誘電率 $\varepsilon$ は (3) 式から求め られる。

$$
\begin{aligned}
R_{x} & =\frac{R_{1} R_{2}}{R_{2}-R_{1}} \\
C_{x} & =C_{1}-C_{2} \cdots \\
\varepsilon & =C_{x} / C_{0}
\end{aligned}
$$

ここに $C_{0}$ は電極閒が真空の場合の容量の值であるが これはあらかじめ誘電率既知の試料の容量測定值から蒸 着電極の乍効面積を求めておけば (4) 式によつて求めら れる。

$$
C_{0}=\frac{S}{4 \pi d}
$$

ここに, $S$ : 蒸着電極の有効面積, $d$ : 試料の厚さ。 本実験の場合，ブラジル産水晶を標準として（ $\varepsilon^{2}=$ 4. 7 $)^{2)} S=1.41 \mathrm{~cm}^{2}$ を得た。測定にあたつては, 試料を まとめて準備し, 出来る限り室内の条件を一定に保ちつ つ一度に測定を行ない，日を改めて再び測定を行なつた が両度の測定值にほとんど差が認められなかつたので, とくに恒温恒湿槽を用いての測定は行なつていない。な お，测定にあたつて従来のように試料に印加する交流電 压を高くすると，容量および電導度に誤差老生ずる懸念 があるので，本実験に拉いては試料に印加される電圧は 常に $5 \mathrm{mV}$ 以下で測定出来るように装置の設計を行なつ た。

（B）実験結果：熱発光を示名石灰岩を（A)，(B), 熱発光を示さないものを（C)，(D)とし，それぞれの測 定值を各周波数について示すと第 1 表のようになる。こ れらの結果から誘電率执よび体積抵抗を各周波数につい て計算して対数目盛で示したものが第 3 図，第 4 図であ る。第 4 図の結果を体積電導度に換算すれば第 5 図のよ らになる。石灰岩試料の熱発光性の有無と誘電率との関 係については十分明らかではないが，電導度の周波数特 性を示す第 5 図をみると, 熱発光石灰岩と非熱発光石灰 岩との間には相違が見られる。すなわち，いずれの試料

\begin{tabular}{|c|c|c|c|c|c|c|c|}
\hline \multirow{2}{*}{$\begin{array}{l}\text { 周波数 } \\
\text { c.p.s. }\end{array}$} & \multicolumn{2}{|c|}{$\begin{array}{l}\text { (A) } d= \\
0.0865 \mathrm{~cm}\end{array}$} & $\begin{array}{l}\text { (B) } d= \\
0.093 \mathrm{~cm}\end{array}$ & \multicolumn{2}{|c|}{ (C) $d=0.105 \mathrm{~cm}$} & \multicolumn{2}{|c|}{ (D) $d=0.110 \mathrm{~cm}$} \\
\hline & $\begin{array}{l}R_{x} \times \\
10^{-6}\end{array}$ & $\begin{array}{l}C_{x} \times \\
10^{-12 F}\end{array}$ & \begin{tabular}{l|l}
$R_{x} \times$ & $C_{x} \times$ \\
$10^{-6} \Omega$ & $10^{-12 \mathrm{~F}}$ \\
\end{tabular} & $\begin{array}{r}R x \times \\
10^{6} \Omega\end{array}$ & $\begin{array}{c}C_{x} \times \\
10^{-12} \mathrm{~F}\end{array}$ & $R_{x} \times$ & $\left\{\begin{array}{l}C_{x} \times \\
10^{-12 \mathrm{~F}}\end{array}\right.$ \\
\hline 30 & 88.0 & 77 & 31 & 38.0 & 27 & 232 & 21 \\
\hline 100 & 47 & 36 & $\begin{array}{ll}2,900 & 20.5\end{array}$ & 47 & 20 & 13 & 2 \\
\hline 300 & 38. & 24 & \begin{tabular}{l|l}
242 & 15.5
\end{tabular} & 32.9 & 16 & 88.0 & 17.5 \\
\hline 1,000 & 23. & 17 & $107 \quad 14.5$ & 30.8 & 13 & & 14.5 \\
\hline 3,000 & 13.6 & 15 & 66.013 & 32.9 & 10 & 47.5 & 13.5 \\
\hline
\end{tabular}
もその電導度は周波数の増大に伴つて増加する傾向が見

第1表 交流ブリッジによる石灰岩の抗捳 および容量の実測值

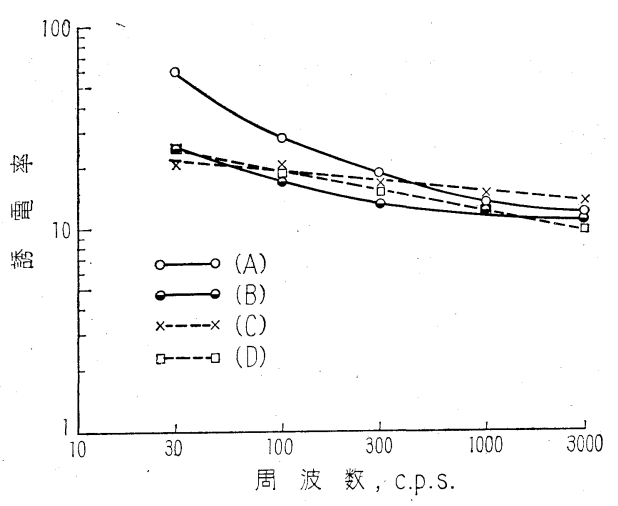

第 3 図石灰岩の誘電率と周波数との関係

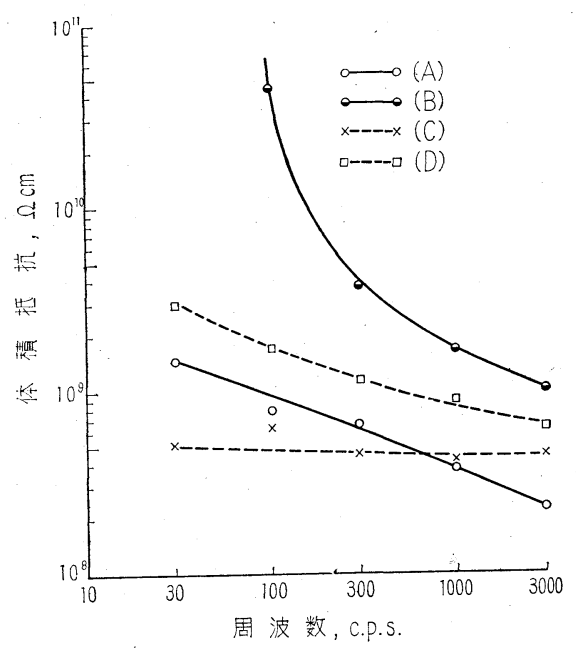

第 4 図石灰岩の体積抵抗と周波数との関係

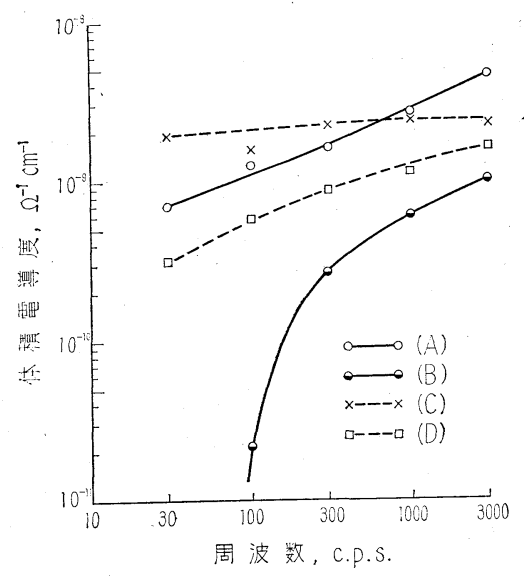

第 5 図 石灰岩の体積電導度と周波数との関係

られるが, 高周波側における電導度の増加の割合は熱発 光石灰岩の方が熱発光を示さないものに比較してより急 激であるように思われる。一般に固体の熱発光現象の原 因は，結晶中の不純物ないしは格子久陥にあるものと考 
えられているが，この考え方にしたがえば熱発光を示す 試料の交流的電導度が周波数の増大にしたがつて増加す ることは妥当な結果を示しているのではないかと思われ る。

\section{$3 \cdot 2$ 電導度滴定によるエチルキサントゲン酸カリウ} ムの微量分析について

浮遊選鉱において捕収剤として用いられるザンセート はその使用量が微量であるために, 稀薄溶液におけるザ ンセートの分析を研究することは有意義なことと考えら れる。この意味において筆者らはさきに高周波滴定装置 を試作し沈殿滴定によつてエチルキサントダン酸カリウ ム (KEtX と略記する) の微量分析を検討したが3), その時においても溶液濃度が $10^{-5} \mathrm{~N}$ になると分析は困 難の状態にあつた。通常のコールラウシユ橋による電導 度滴定ではこの濃度の分析が困難であることはいらまで もない。そこで本試作ブリッジを使用して K Et X の沈 殿滴定による微量分析を行なつてみた。

被検液は $5 \times 10^{-5} \mathrm{~N}, 1 \times 10^{-5} \mathrm{~N}, 5 \times 10^{-6}$, N の K Et X 溶液 $100 \mathrm{cc}$, 滴定液は $1 \times 10^{-3} \mathrm{~N}$ 硝酸銀溶液孝用い, 、 イクロビニレットにより滴定を行なつた。結果を第 6 図 に示す。同図において, それぞれの濃度の K EtX 溶液に 対する横軸は， $1 \times 10^{-3} \mathrm{~N}$ 硝酸銀溶液の添加量を, 縦軸

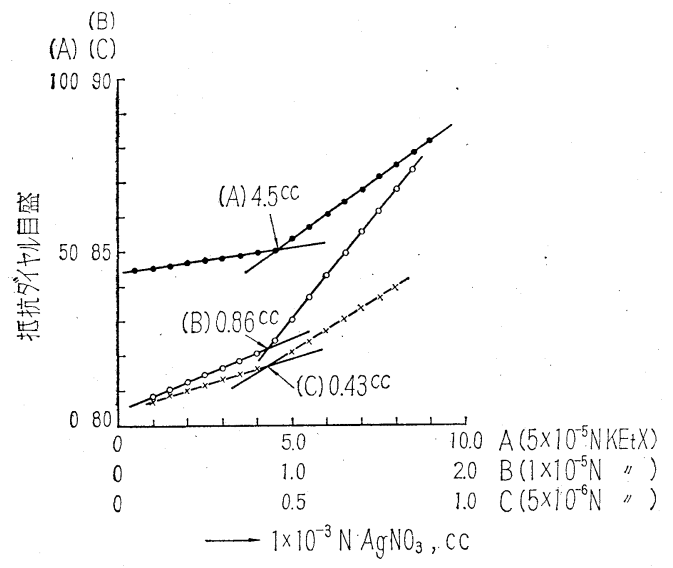

第6 図 笔導度滴定にょる $\mathrm{KEtX}$ 溶液の分析
は抵抗ダイヤル目盛をそのまま示してある。滴定の終点 は2 本の直線の交点によつて示されるが, 図为らわかる ように各終点はほぼ検液濃度に比例した結果を与えてお り, $5 \times 10^{-6} \mathrm{~N}$ 程度迄の $\mathrm{K} \mathrm{Et} \mathrm{X}$ 溶液の定量が可能であ ることがわかる。

以上，高インピーダンス用低周波交流ブリッジの試作 の概要と, 性能試験を兼社て若干の応用測定を行なつた 結果を述べ, 従来の交流ブリッジで測定困難な場合にも 比較的精度の良い結果の得られることが明らかにされ た。しかしながら, まだ平衡差動増幅部, 狭帯域増幅部 などに改良の余地が残されており,さらにブリッジ辺の コンデンサーは標準コンデンサーを使用するなどの点を 改めれば，現在よりも広䈯囲な周波数範囲において，さ らに良い感度, 精度あるいは確度で測定が行なわれるこ とが期待されるものである。

\section{4. 要約}

高インピーダンス用低周波交流ブリッジを試作し，試 作装置の性能試験を兼ねて石灰岩の誘電率, 電導度など の周波数特性 (30 3, 000 サイクル),電導度滴度による $\mathrm{KEtX}$ 溶液の微量分析を行なつた。

石灰岩は測定インピーダンス值 $10^{-9} \sim 10^{-10} \Omega$ の試料 においても比較的精度良く測定を行なうことが出来, 熱 発光石灰岩は熱発光を示さないものに比較して周波数の 増大に伴う電導度の増加がより急激であることが示され た。K Et X は $1 \times 10^{-3} \mathrm{~N}$ 硝酸銀溶液を滴定液とする沈 殿滴定によつて $5 \times 10^{-6} \mathrm{~N}$ 溶液の濃度まで定量可能であ つた。

本実験を行ならにあたり, 種々御援助を頂いた東北大 学工学部鈴木廉三九教授に感謝の意を表する。また，実 験に協力を頂いた牛田稔工学士, 鈴木茂工学士に併せて 感謝の意を表する次第である。

\section{文献}

1) 早川典久: Tech. Rep. Tohcku Univ. Vol. XXII No. 2, 1958.

2) 水島三一郎 : 電波々物質, 岩波 (昭 21 年) 附表 1

3) 大山正・下飯坂潤三・日井進之助 : 東北釷山, 2 巻 2 号 15 頁 (昭 30 ) 